\title{
Copper Ions Enhance Signal Intensity of Sandwich ELISA for Amorphous Aggregates of Amyloid- $\beta_{42}$
}

\author{
Akira Itakura1, Yoshio F. Kanematsu' ${ }^{1}$, Ryoko Suzuki¹, Hideki Kohno², Kazuaki Yoshimune ${ }^{1 *}$ \\ ${ }^{1}$ Department of Applied Molecular Chemistry, Graduate School of Industrial Technology, Nihon University, Chiba, Japan \\ ${ }^{2}$ Hoshi University, Tokyo, Japan \\ Email: *yoshimune.kazuaki@nihon-u.ac.jp
}

How to cite this paper: Itakura, A., Kanematsu, Y.F., Suzuki, R., Kohno, H. and Yoshimune, K. (2016) Copper Ions Enhance Signal Intensity of Sandwich ELISA for Amorphous Aggregates of Amyloid- $\beta_{42}$. Advances in Bioscience and Biotechnology, 7, 343-349.

http://dx.doi.org/10.4236/abb.2016.79033

Received: June 16, 2016

Accepted: August 19, 2016

Published: August 22, 2016

Copyright $\odot 2016$ by authors and Scientific Research Publishing Inc. This work is licensed under the Creative Commons Attribution International License (CC BY 4.0).

http://creativecommons.org/licenses/by/4.0/

\begin{abstract}
Amyloid- $\beta_{42}\left(A \beta_{42}\right)$ accumulates within senileplaque, a pathological hall mark of Alzheimer's disease (AD). Our previous reports showed that the monoclonal antibodies 37-11 and 77-3 react with conformational epitopes on the surface of the soluble aggregates of $A \beta_{42}$ and that sandwich ELISA using these two monoclonal antibodies yields high reactivity to detect soluble aggregates of $A \beta_{42}$. Here, the reactivity of the sandwich ELISA was shown to increase in the presence of $50 \mu \mathrm{M} \mathrm{Cu}^{2+}$. However, the addition of $\mathrm{Cu}^{2+}$ had only a small effect on the reactivity of a direct ELISA using antibody 37-11 or 77-3, suggesting that $\mathrm{Cu}^{2+}$ has a small effect on the number of epitopes on the surface of the aggregates. Atomic force microscopy images showed that larger aggregates were formed in the presence of $\mathrm{Cu}^{2+}$, as shown in the other reports. $\mathrm{Cu}^{2+}$ may gather the aggregates with distinct epitopes recognized by antibodies 37-11 and 77-3, leading to increased signal intensity of the sandwich ELISA.
\end{abstract}

\section{Keywords}

Amyloid- $\beta_{42}$, Soluble Aggregates, Antibody, ELISA

\section{Introduction}

One of major hallmarks of Alzheimer's disease (AD) is the formation of senile plaques, mainly consisting of amyloid beta protein $(A \beta)$, in the brains of patients [1] [2]. Under physiological conditions, $A \beta$ are produced by the partial digestions of amyloid precursor proteins; most $A \beta$ s consist of 40 amino acids $\left(A \beta_{40}\right)$, though approximately $10 \%$ are 42 amino acids in length $\left(A \beta_{42}\right)$ [3]. $A \beta_{42}$ has higher hydrophobicity, and thus a higher tendency to aggregate compared to $A \beta_{40}$; therefore, $A \beta_{42}$ appears to be the more toxic variant [4]. $A \beta_{42}$ forms two distinct aggregates known as fibrillar and amorphous forms. 
The fibrillar form has an antiparallel $\beta$-sheet structure, and is the main component of senile plaques [5]. The fibril formation is formed from the conversion of monomers to oligomers and subsequently to protofibrils and fibrils [6]. The amorphous aggregates are less structured and lack the ability to form fibrils. They are found in diffuse plaques [7] and senile plaques in the brains of AD patients [8]. Various sizes of amorphous aggregates have been reported ranging from trimers to sub-micrometer orders [9]-[11]. Large oval aggregates (LOA), which are amorphous aggregates greater than $200 \mathrm{~nm}$ in their minor axis, are generated by the addition of peptide $A \beta_{16-20}$ [12]. $A \beta_{16-20}$ includes the region essential for the fibril formation in $A \beta$ but prevents fibril formation to produce LOAs. As previously described [13], soluble aggregates are prepared by dissolving $\mathrm{A} \beta_{42}$ in 1,1,1,3,3,3-hexafluoro-2-propanol in the absence of $\mathrm{A} \beta_{16-20}$. The soluble aggregates include various sizes of amorphous aggregates ranging from 20 to $400 \mathrm{~nm}$. Metal ions such as $\mathrm{Cu}^{2+}$ bind to $\mathrm{A} \beta$ affecting the formation of aggregates. Many reports show that $\mathrm{Cu}^{2+}$ binding changes the surface charge of $A \beta$ and enhances amorphous aggregate formation by preventing fibril formation [14]-[18]. A $\beta_{42}$ in cerebrospinal fluid (CSF) is a clinical biomarker for $\mathrm{AD}$ [19] [20]. In $\mathrm{AD}$ patients, the concentration of $\mathrm{A} \beta_{42}$ decreases, as it is incorporated into senile plaques, whereas the concentration of $A \beta_{40}$ is unchanged. The average concentration of $A \beta_{42}$ in spinal fluid is less than $200 \mathrm{Pm}$ [19]. Therefore, highly sensitive detection of $A \beta_{42}$ is desirable for $A D$ diagnosis. Our previous reports identified various monoclonal antibodies with reactivity against $A \beta$ aggregates, but with little reactivity against the fibril and monomer forms [8] [12] [13] [21]. Among them, antibody 37-11 was determined to react with LOA [12], and antibody 77-3 could react with both LOA and soluble aggregates [13]. Sandwich ELISA using these two antibodies resulted in the highly sensitive detection of soluble aggregates. In this report, the reactivity of the sandwich ELISA was shown to increase through the addition of $50 \mu \mathrm{M} \mathrm{Cu}^{2+}$; however, the addition had only a small effect on the reactivity of each antibody. $\mathrm{Cu}^{2+}$ could gather aggregates to form large aggregates with two distinct epitopes that were specifically recognized by antibodies $77-3$ and $37-11$.

\section{Materials and Methods}

\subsection{Preparation of the Soluble Aggregates}

Soluble amorphous aggregates were prepared as previously described [21]. Briefly, 0.11 $\mathrm{mM} \mathrm{A} \beta_{42}$ (Peptide Institute Inc., Osaka, Japan) was dissolved in 1,1,1,3,3,3-hexafluoro-2-propanol, and incubated at $4^{\circ} \mathrm{C}$ for $16 \mathrm{~h}$ followed by $37^{\circ} \mathrm{C}$ for $3 \mathrm{~h}$, after which the solution was lyophilized. The steps including dissolution and lyophilization were repeated twice, and lyophilized $A \beta_{42}$ was dissolved in deionized water. The concentration of $A \beta_{42}$ in the solution was determined by its absorbance at $280 \mathrm{~nm}$ using the molar extinction coefficient of $1450 \mathrm{M}^{-1} \mathrm{~cm}^{-1}$ of $\mathrm{A} \beta_{42}$, which has one tyrosine residue and no tryptophan residues.

\subsection{Enzyme-Linked Immunosorbent Assay (ELISA)}

Direct ELISA was performed as previously described [12]. The soluble aggregates (100 
$\mu \mathrm{l})$ were used as solid-phase antigens, and were stained on 96-well plates (F96 MAXISORP NUNC-IMMUNO PLATE; Thermo Fisher Scientific Inc., Rochester, NY, USA). The monoclonal antibody 37-11 or 77-3, previously conjugated to HRP using a Peroxidase Labeling Kit-SH (Dojindo Molecular Technologies Inc., Kumamoto, Japan), was used as a primary antibody. The substrate SIGMAFAST OPD (Sigma-Aldrich, St. Louis, MO) was used for color development according to the manufacturer's instructions. For sandwich ELISA, the antibody 77-3 was used as the primary antibody, and HRP-conjugated antibody 37-11 was used as the secondary antibody as described previously [13].

\subsection{Atomic Force Microscopy}

The sizes and shapes of the aggregates were observed by atomic force microscopy (AFM, JSPM-5200, JEOL Ltd, Tokyo, Japan) as previously described [12]. The aggregates $(10 \mu \mathrm{l})$ were dropped on fresh mica and dried by desiccation, and measured using the altering current mode at room temperature, with a frequency of approximately 190 $\mathrm{kHz}$, typical of resonances with a $4.5 \mathrm{~N} / \mathrm{m}$ spring constant.

\section{Results and Discussion}

\section{1. $\mathrm{Cu}^{2+}$ Increases Signal Intensity of Soluble Aggregates during Sandwich ELISA}

Metal ions are known to bind to $A \beta$ and induce the formation of the amorphous aggregates. Metal ions were hypothesized to change the conformation of the epitopes, recognized by antibodies 37-11 and 77-3, and used for the highly sensitive detection of soluble aggregates. Various metal ions ( $50 \mu \mathrm{M} \mathrm{MnCl}_{2}, \mathrm{FeCl}_{2}, \mathrm{NiCl}_{2}, \mathrm{CuCl}_{2}$, or $\mathrm{ZnCl}_{2}$ ) were added to the soluble aggregates and signal intensities were observed after sandwich ELISA using the two antibodies. The addition of $\mathrm{CuSO}_{4}$ increased the signal intensity approximately 9.1-fold; however, the effect of other metal ions had little effect on signal intensities (data not shown). This result is consistent with the previous reports suggesting that binding of $\mathrm{Cu}^{2+}$ to $A \beta$ is stronger than that of other metal ions. Thus, the increased signal intensity was considered to be caused by $\mathrm{Cu}^{2+}$ binding to $\mathrm{A} \beta$ The effect of different concentrations of $\mathrm{CuSO}_{4}$ on the signal intensity of soluble aggregates in the sandwich ELISA is shown in Figure 1. The signal increased in the presence of $10 \mu \mathrm{M} \mathrm{CuSO}_{4}$, and reached a maximum in the presence of $\mathrm{CuSO}_{4}$ ranging in concentration from 25 to $75 \mu \mathrm{M}$. These concentrations of $\mathrm{Cu}^{2+}$ were much higher than those of $\mathrm{A} \beta(130 \mathrm{nM}$ in $100 \mu \mathrm{l})$, used for the ELISA, and may have induced the formation of amorphous aggregates. Some studies have shown that $\mathrm{Cu}^{2+}$ at sub-equimolar metal ion $/ \mathrm{A} \beta_{42}$ ratios induces the formation of fibrils, whereas supra-molar ratios induce the formation of non-fibrillar forms [15]. In addition, the $\mathrm{Cu}^{2+}$ concentrations in this report were similar to those found in the serum $(7-41 \mu \mathrm{M})$ [22]. Figure 2 shows the effects of $\mathrm{CuSO}_{4}$ and $\mathrm{CuCl}_{2}$ on the signal intensities of the sandwich ELISA. The effect of $\mathrm{CuCl}_{2}$ was greater than that of $\mathrm{CuSO}_{4}$ suggesting that the counter anion also affects signal intensity. 


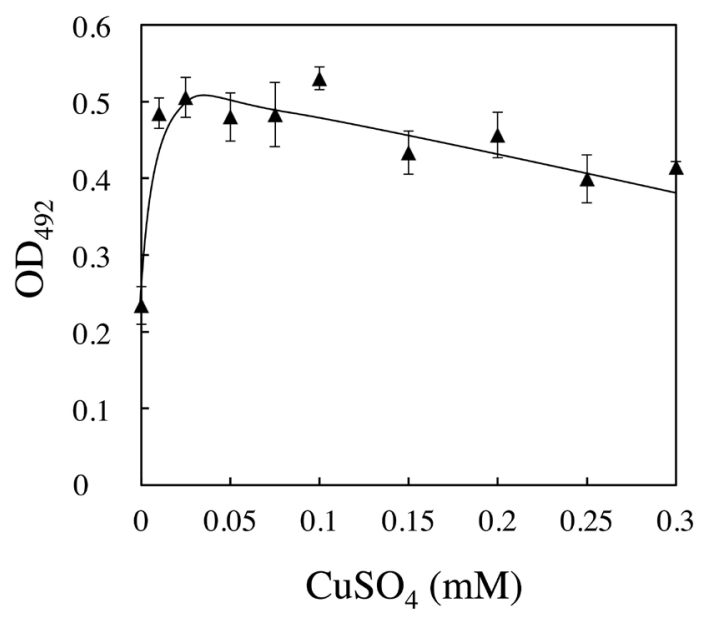

Figure 1. Effect of $\mathrm{CuSO}_{4}$ concentrations on the signal intensity of the sandwich ELISA. Sandwich ELISA was performed using the antibody 77-3 as a primary antibody and HRP-conjugated antibody $37-11$ as a secondary antibody. The reactivity of the soluble aggregates ( $13 \mathrm{pmol})$, in the presence and absence of various concentrations of $\mathrm{Cu}^{2+}$, was determined.

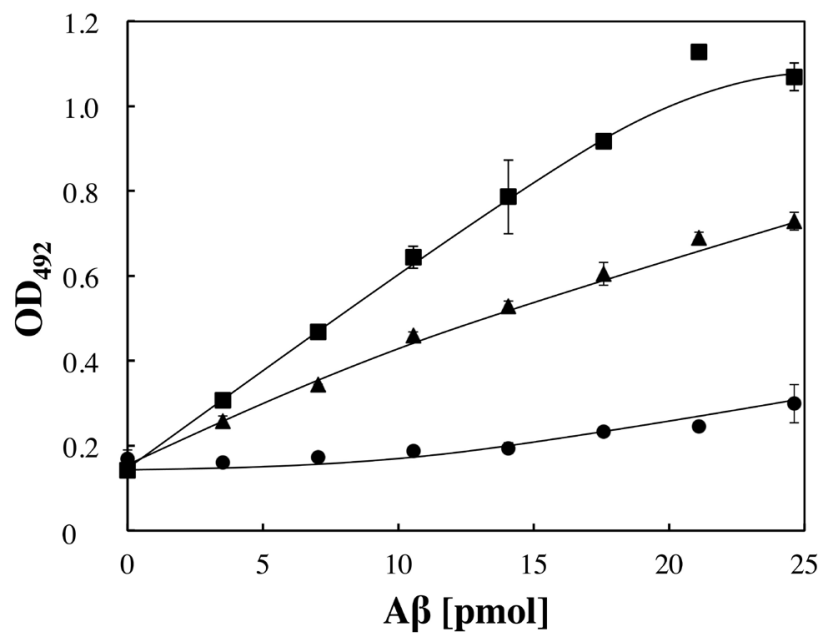

Figure 2. Effect of $\mathrm{CuSO}_{4}$ and $\mathrm{CuCl}_{2}$ on the signal intensity of the sandwich ELISA. Sandwich ELISA using the antibodies 37-11 and 77-3 was performed in the absence (circles) and presence of $50 \mu \mathrm{M} \mathrm{CuSO}_{4}$ (triangles) or $\mathrm{CuCl}_{2}$ (squares).

\section{2. $\mathrm{Cu}^{2+}$ Has Little Effect on the Signal Intensity of the Soluble Aggregates from Direct ELISA}

It is possible that the epitopes, recognized by antibodies 37-11 and 77-3, are formed on the surface of soluble aggregates in the presence of $\mathrm{Cu}^{2+}$. To evaluate the formation of new epitopes, direct ELISA was performed. Figure 3 shows the effect of $50 \mu \mathrm{M} \mathrm{CuCl}_{2}$ on signal intensities. Unlike the results of the sandwich ELISA (Figure 2), $\mathrm{Cu}^{2+}$ only minimally enhanced the signal intensity. These results suggest that $\mathrm{Cu}^{2+}$ increases the intensity by gathering distinct aggregates with two distinct epitopes recognized by antibodies 37-11 and 77-3, rather than generating these epitopes. The AFM images (Figure 4), showing the formation of larger aggregates through the addition of $\mathrm{Cu}^{2+}$, were 


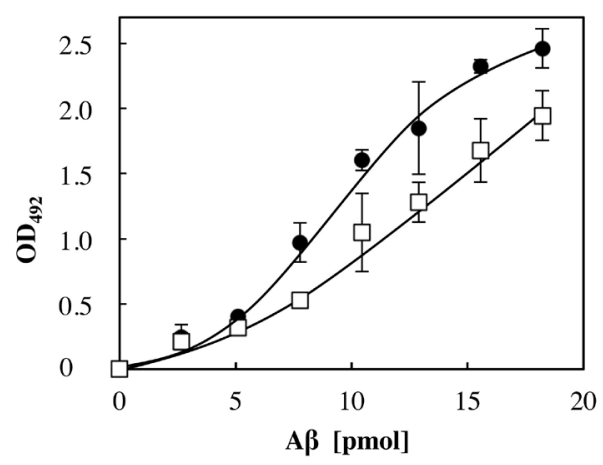

(a)

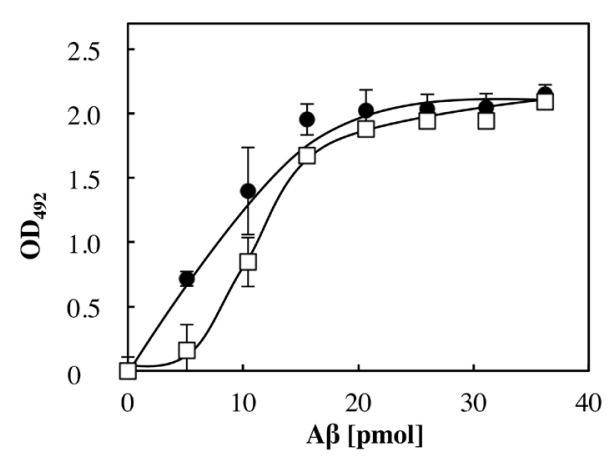

(b)

Figure 3. Effect of $\mathrm{CuCl}_{2}$ on the signal intensity of the direct ELISA. Direct ELISA using HRP-conjugated antibody 37-11 (a) or 77-3 (b) was performed in the absence (open squares) and the presence of $50 \mu \mathrm{M} \mathrm{CuCl}_{2}$ (closed circles).

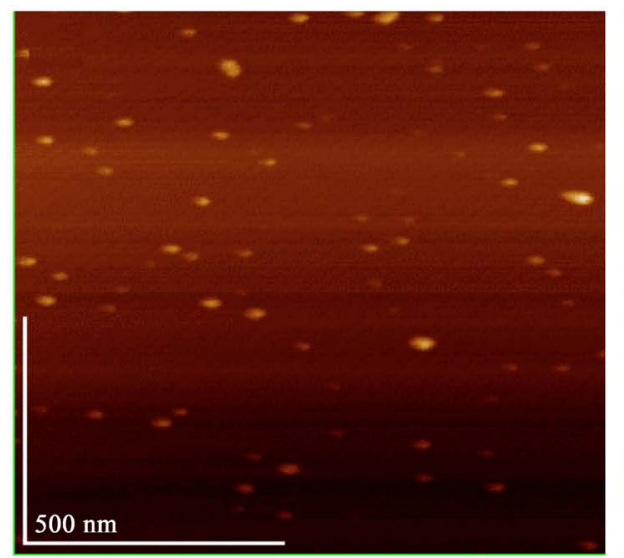

(a)

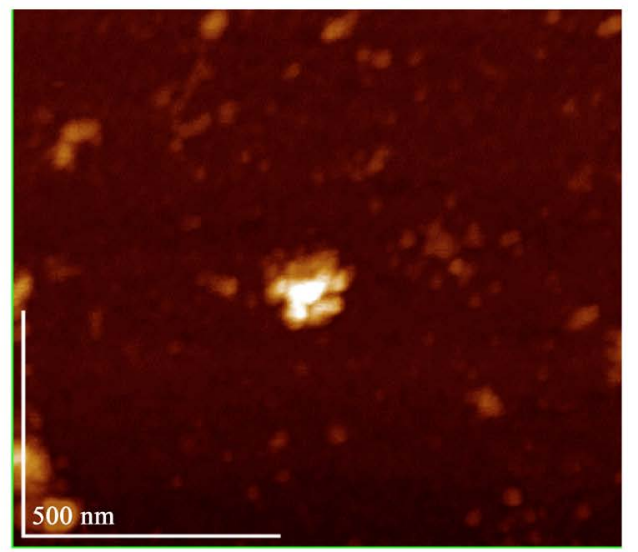

(b)

Figure 4. AFM images of soluble aggregates. Soluble aggregates in the absence (a) and presence (b) of $50 \mu \mathrm{M} \mathrm{CuCl}_{2}$ are shown.

consistent with this theory. Based on this hypothesis, the epitopes recognized by antibodies 37-11 and 77-3 might be separately located on the surface of distinct aggregates, and few aggregates have both epitopes on their surface.

This report shows that the addition of $\mathrm{Cu}^{2+}$ increases the reactivity of the sandwich ELISA for soluble aggregates. This finding could contribute to the development of a precise and highly sensitive ELISA for $A \beta$ aggregates by enhancing the reactivity of the antibodies.

\section{References}

[1] Awasthi, M., Singh, S., Pandey, V.P. and Dwivedi, U.N. (2016) Alzheimer's Disease: An Overview of Amyloid Beta Dependent Pathogenesis and Its Therapeutic Implications along with In Silico Approaches Emphasizing the Role of Natural Products. Journal of Neurological Sciences, 361, 256-271. http://dx.doi.org/10.1016/j.jns.2016.01.008

[2] Hardy, J.A. and Higgins, G.A. (1992) Alzheimer's Disease: The Amyloid Cascade Hypothesis. Science, 256, 184-185. http://dx.doi.org/10.1126/science.1566067 
[3] vanOijen, M., Hofman, A., Soares, H.D., Koudstaal, P.J. and Breteler, M.M. (2006) Plasma Abeta(1-40) and Abeta(1-42) and the Risk of Dementia: A Prospective Case-Cohort Study. Lancet Neurology, 5, 655-660. http://dx.doi.org/10.1016/S1474-4422(06)70501-4

[4] Suzuki, N., Cheung, T.T., Cai, X.D., Odaka. A., Otvos, L. Jr., Eckman, C., Golde, T.E. and Younkin, S.G. (1994) An Increased Percentage of Long Amyloid Beta Protein Secreted by Familial Amyloid Beta Protein Precursor (Beta APP717) Mutants. Science, 264, 1336-1340. http://dx.doi.org/10.1126/science.8191290

[5] Chimon, S., Shaibat, M.A., Jones, C.R., Calero, D.C., Aizezi, B. and Ishii, Y. (2007) Evidence of Fibril-Like $\beta$-Sheet Structures in a Neurotoxic Amyloid Intermediate of Alzheimer's $\beta$-Amyloid. Nature Structural \& Molecular Biology, 14, 1157-1164. http://dx.doi.org/10.1038/nsmb1345

[6] O'Nuallain, B., Freir, D.B., Nicoll, A.J., Risse, E., Ferguson, N., Herron, C.E., Collinge, J. and Walsh, D.M. (2010) Amyloid Beta-Protein Dimers Rapidly Form Stable Synaptotoxicprotofibrils. The Journal of Neuroscience, 30, 14411-14419. http://dx.doi.org/10.1523/JNEUROSCI.3537-10.2010

[7] Dickson, D.W. (1997) The Pathogenesis of Senile Plaques. Journal of Neuropathology \& Experimental Neurology, 56, 1285-1290. http://dx.doi.org/10.1097/00005072-199704000-00001

[8] Ochiishi, T., Itakura, A., Liu, L., Akatsu, H., Kohno, H., Nishimura, M. and Yoshimune, K. (2016) Immunohistochemical Detection of the Delayed Formation of Nonfibrillar Large Amyloid- $\beta$ Aggregates. Genes Cells, 21, 200-211. http://dx.doi.org/10.1111/gtc.12332

[9] Lambert, M.P., Barlow, A.K., Chromy, B.A., Edwards, C., Freed, R., Liosatos, M., Morgan, T.E., Rozovsky, I., Trommer, B., Viola, K.L. and other 5 authors (1998) Diffusible, Nonfibrillar Ligands Derived from Abeta1-42 Are Potent Central Nervous System Neurotoxins. The Proceedings of the National Academy of Sciences of the United States of America, 95, 6448-6453. http://dx.doi.org/10.1073/pnas.95.11.6448

[10] Barghorn, S., Nimmrich, V., Striebinger A., Krantz, C., Keller, P., Janson, B., Bahr, M., Schmidt, M., Bitner, R.S., Harlan, J., et al. (2005) Globular Amyloid Beta-Peptide Oligomer -A Homogenous and Stable Neuropathological Protein in Alzheimer's Disease. Journal of Neurochemistry, 95, 834-847. http://dx.doi.org/10.1111/j.1471-4159.2005.03407.x

[11] Matsumura, S., Shinoda, K., Yamada, M., Yokojima, S., Inoue, M., Ohnishi, T., Shimada, T., Kikuchi, K., Masui, D., Hashimoto, S. and other 14 authors (2011) Two Distinct Amyloid Beta-Protein (Abeta) Assembly Pathways Leading to Oligomers and Fibrils Identified by Combined Fluorescence Correlation Spectroscopy, Morphology, and Toxicity Analyses. Journal of Biological Chemistry, 286, 11555-11562. http://dx.doi.org/10.1074/jbc.M110.181313

[12] Shimizu, T., Yoshimune, K., Komoriya, T., Akiyama, T., Ye, X. and Kohno, H. (2013) Monoclonal Antibodies against Large Oval Aggregates of A $\beta 1-42$. Journal of Bioscience and Bioengineering 115, 216-220. http://dx.doi.org/10.1016/j.jbiosc.2012.09.007

[13] Shimizu, T., Yoshimune, K., Komoriya, T., Akiyama, T., Ye, X. and Kohno, H. (2013) Combination of Specific Monoclonal Antibodies Allow Identification of Soluble Aggregates of A $\beta 1-42$ by Sandwich ELISA. Advances in Bioscience and Biotechnology, 4, 63-66. http://dx.doi.org/10.4236/abb.2013.44A009

[14] Branch, T., Girvan, P., Barahona, M. and Ying, L. (2015) Introduction of a Fluorescent Probe to Amyloid- $\beta$ to Reveal Kinetic Insights into Its Interactions with Copper(II). Angewandte Chemie International Edition, 54, 1227-1230. http://dx.doi.org/10.1002/anie.201408810

[15] Ryan, T.M., Kirby, N., Mertens, H.D., Roberts, B., Barnham, K.J., Cappai, R., Pham, Cle L., Masters, C.L. and Curtain, C.C. (2015) Small Angle X-Ray Scattering Analysis of 
$\mathrm{Cu}(2+)$-Induced Oligomers of the Alzheimer's Amyloid $\beta$ Peptide. Metallomics, 7, 536-543. http://dx.doi.org/10.1039/C4MT00323C

[16] Jiang, D., Rauda, I., Han, S., Chen, S. and Zhou, F. (2012) Aggregation Pathways of the Amyloid $\beta$ (1-42) Peptide Depend on Its Colloidal Stability and Ordered $\beta$-Sheet Stacking. Langmuir, 28, 12711-12721. http://dx.doi.org/10.1021/la3021436

[17] Shimanouchi, T., Onishi, R., Kitaura, N., Umakoshi, H. and Kuboi, R. (2011) Copper-Mediated Growth of Amyloid $\beta$ Fibrils in the Presence of Oxidized and Negatively Charged Liposomes. Journal of Bioscience and Bioengineering, 112, 611-615. http://dx.doi.org/10.1016/j.jbiosc.2011.08.015

[18] Tõugu, V., Karafin, A., Zovo, K., Chung, R.S., Howells, C., West, A.K. and Palumaa, P. (2009) Zn(II)- and Cu(II)-Induced Non-Fibrillar Aggregates of Amyloid-Beta (1-42) Peptide Are Transformed to Amyloid Fibrils, Both Spontaneously and Under the Influence of Metal Chelators. Journal of Neurochemistry, 110, 1784-1795. http://dx.doi.org/10.1111/j.1471-4159.2009.06269.x

[19] Blennow, K., Mattsson, N., Schöll, M., Hansson, O. and Zetterberg, H. (2015) Amyloid Biomarkers in Alzheimer's Disease. Trends in Pharmacological Sciences, 36, 297-309. http://dx.doi.org/10.1016/j.tips.2015.03.002

[20] Hölttä, M., Hansson, O., Andreasson, U., Hertze, J., Minthon, L., Nägga, K., Andreasen, N., Zetterberg, H. and Blennow, K. (2013) Evaluating Amyloid- $\beta$ Oligomers in Cerebrospinal Fluid as a Biomarker for Alzheimer's Disease. PLoS One, 8, e66381. http://dx.doi.org/10.1371/journal.pone.0066381

[21] Shimizu, T., Yoshimune, K., Komoriya, T., Ogawa, M., Akiyama, T., Ye, X. and Kohno, H. (2015) Classification of Monoclonal Antibodies to Measure the Progress of A $\beta 1$-42 Aggregation. Global Journal for Research Analysis, 4, 117-119.

[22] Twomey, P.J., Viljoen, A., House, I.M., Reynolds, T.M. and Wierzbicki, A.S. (2005) Relationship between Serum Copper, Ceruloplasmin, and Non-Ceruloplasmin-Bound Copper in Routine Clinical Practice. Clinical Chemistry, 51, 1558-1559. http://dx.doi.org/10.1373/clinchem.2005.052688

Submit or recommend next manuscript to SCIRP and we will provide best service for you:

Accepting pre-submission inquiries through Email, Facebook, LinkedIn, Twitter, etc. A wide selection of journals (inclusive of 9 subjects, more than 200 journals)

Providing 24-hour high-quality service

User-friendly online submission system

Fair and swift peer-review system

Efficient typesetting and proofreading procedure

Display of the result of downloads and visits, as well as the number of cited articles

Maximum dissemination of your research work

Submit your manuscript at: http://papersubmission.scirp.org/ 